\title{
LENGTH OF WORKING AND LOW BACK PAIN IN HEALTH WORKERS: A META-ANALYSIS
}

\author{
Muh. Syaiful Akbar'), Bhisma Murti'),Setyo Sri Rahardjo²), Dono Indarto²) \\ 1)Masters Program in Public Health, Universitas Sebelas Maret \\ 2)Faculty of Medicine, Universitas Sebelas Maret
}

\begin{abstract}
Background: Low back pain is the result of an injury, such as muscle sprains or strains due to sudden movements or poor body mechanics while lifting heavy objects. Low back pain can also be the result of certain diseases. There are various physical and psychosocial risk factors that cause LBP in nurses. This study was to examine length of working anfdlow back pain health workers.

Subjects and Method: A meta-analysis and systematic review was conducted by collected published articles toward length of working and low back pain in health workers. The articled were obtained from Pubmed, Science Direct, Scopus, Google Scolar, and Springer Link databases. Keywords used to search the related articles including "risk factor, low back pain, medical person, health workers, cross Sectional”. Full text articles with cross-sectional study design were analyzed using PRISMA guidelines and Review Manager 5.4.

Results: Length of working $\square 6$ hours per day increased the risk of low back pain in health workers, but it was statistically non-significant $(\mathrm{aOR}=1.53 ; 95 \% \mathrm{CI}=0.71$ to $3.29 ; \mathrm{p}=0.280)$. Conclusion: Length of working $\square 6$ hours per day increases the risk of low back pain in health workers.
\end{abstract}

Keywords: length of working, low back pain, meta-analysis

Correspondence:

Muh. Syaiful Akbar. Masters Program in Public Health, Universitas Sebelas Maret. Jl. Ir. Sutami 36A, Surakarta 57126, Central Java. Email:asyaifulop@gmail.com. Mobile: 082325070569.

The $7^{\text {th }}$ International Conference on Public Health

Solo, Indonesia, November 18-19, 2020 | 96

https://doi.org/10.26911/the7thicph.01.51 